\title{
ANALISIS DAN PENGUKURAN IT ALIGNMENT KASUS PADA PT. WILLIAM MAKMUR PERKASA
}

\author{
Anneke Wangkar \\ (Email : annekewangkar@yahoo.com)
}

\begin{abstract}
Entering the era of information and free trade, the company requires a certain superiority in the face of competition nationally and internationally. For every company that strives to provide the best service facilities for customers via the accuracy, precision and effectiveness information. These things must be supported by the development of information technology at the moment.

Therefore, the information technology department to evaluate the results of implementing the system using a Maturity Model of COBIT (Control Objectives for Information and related Technology).

Maturity Model is a way to measure how well the progress of the company's IT management processes. These measurements by using scales or limits (0 to 5) as a practical example in determining the levels of IT management capabilities at every level of ability. From the company level can be compared with the target company and references COBIT Maturity Model and reality on the ground.
\end{abstract}

Keywords : Kepatuhan, prosedur, Maturity Model, COBIT, Standar

\section{PENDAhUluAN}

\subsection{Latar Belakang Masalah}

Memasuki era informasi dan perdagangan bebas ini, perusahaan memerlukan satu keunggulan tertentu guna menghadapi persaingan secara nasional dan internasional. Untuk itu setiap perusahaan berusaha untuk memberikan fasilitas pelayanan yang terbaik bagi pelanggan melalui keakuratan, ketepatan dan keefektifan informasi. Hal-hal tersebut haruslah ditunjang dengan perkembangan teknologi informasi pada saat ini.

Oleh karenanya perusahaan dapat mengantisipasi sistem yang digunakan untuk perusahaannya dengan membuat kriteria dan daftar kebutuhan perusahaan. Melalui kriteria dan daftar kebutuhan tersebut, perusahaan dapat menginvestasikannya di bidang teknologi informasi.

Namun demikian, investasi teknologi informasi ini membutuhkan biaya dan resiko yang tinggi namun dapat memberikan keuntungan dan keunggulan yang sesuai dengan kriteria dan kebutuhan perusahaan.

Investasi ini diwujudkan dalam bentuk komputer dengan jaringan komputer (perangkat keras), software (perangkat lunak) dan sumber daya manusia dimana perkembangannya sangat cepat dan pesat. Disamping itu perlu adanya pelatihan bagi sumber daya manusia dalam pengguna teknologi informasi tersebut, guna mengantisipasi pelaksanaan sistem teknologi informasi.

Oleh karenanya, departemen teknologi informasi dapat mengevaluasi hasil pelaksanaan sistem tersebut dengan menggunakan survey. Survey ini digunakan untuk menganalisa penggunaan sistem teknologi informasi, apakah telah sejalan dengan keinginan manajemen ataukah perlu adanya beberapa perubahan strategi. 


\subsection{Rumusan Masalah}

Berdasarkan uraian latar belakang masalah di atas maka dirumuskan masalah penelitian sebagai berikut :

1. Apakah Sistem Teknologi Informasi telah memberikan satu keuntungan yang spesifik bagi perusahaan

2. Apakah Sistem Teknologi Informasi telah sejalan dengan strategi yang diinginkan oleh perusahaan?

3. Variabel apa saja yang mempengaruhi? Apakah variabel-variabel tersebut memberikan kontribusi yang positif atau sebaliknya?

\section{LANDASAN TEORI}

\subsection{Perkembangan Bisnis}

Persaingan adalah satu kata penting di dalam menjalankan perusahaan pada saat ini. Hal ini ditunjang dengan perkembangan teknologi komunikasi yang semakin pesat dan ditambah dengan era dunia memasuki pasar bebas. Karenanya, setiap perusahaan berusaha untuk mengantisipasi perubahan melalui satu keunggulan.

Adapun alasannya sebagai berikut:

a. Ketepatan Waktu Ketepatan waktu diperlukan untuk memenuhi permintaan pelanggan dan merupakan salah satu indikator keunggulan dalam persaingan. Untuk itu diperlukan restrukturisasi proses kerja dan reorganisasi perusahaan supaya mendapatkan kecepatan dalam memenuhi ketepatan waktu.

b. Harga murah. Harga murah merupakan indikator keunggulan persaingan selain ketepatan waktu. Untuk memenuhinya, perusahaan berusaha untuk memangkas unsur biaya pembelian infrastuktur sistem informasi pada perusahaan.

c. Kualitas produk tinggi dan pelayanan. Perusahaan diharapkan memberikan kualitas produk tinggi dan memberikan pelayanan yang memuaskan pelanggan serta dilaksanakan secepat mungkin.

d. Perubahan bisnis secara global. Dengan adanya jaringan dunia, internet dan intranet maka pelanggan tidak tergantung dengan tempat dan jarak pelanggan itu sendiri.

e. Perubahan kebijakan. Perubahan kebijakan ini terjadi karena adanya kemajuan pada teknologi informasi dimana pegawai dapat melakukan pekerjaan selain di kantor. Contohnya di rumah dan kendaraan (mobil dan pesawat). Demikian juga dengan pelanggan, mereka dapat mengetahui produk yang dihasilkan melalui internet ataupun intranet. Hal ini menyebabkan kebijakan perusahaan berubah, sehingga pelanggan atau pegawai dapat saling berkomunikasi secara virtual tanpa harus saling bertemu atau bertatap muka.

\subsection{IT Alignment}

\subsubsection{Apakah Kesesuaian IT itu?}

Alignment diartikan sebagai kesesuaian sehingga IT Alignment adalah kesesuaian perencanaan IT secara keseluruhan baik kepemimpinan, struktur organisasi, peralatan hardware dan software dengan tujuan perusahaan.

Kesesuaian dibutuhkan pada saat (a) pengambilan keputusan yang penting seperti akuisisi, kerjasama, dan outsourcing, (b) penentuan pemasok atau suatu produk atau mengakuisisi suatu perusahaan, (c) pemeriksaan produktifitas suatu fungsi dan infrastruktur dari 
pemasok atau pengakuisisian perusahaan, (d) kebutuhan atas informasi mengenai kemampuan, kultur dan pelaksanaan operasional, (e) mengetahui hal-hal penting seperti kapabilitas, resiko, pengetahuan mengenai proses dan informasi tentang pelanggan, (f) menuntut untuk memperoleh jasa yang memuaskan dan dengan agresif menuntut proses yang baik dan tanggung jawab.

Semuanya digunakan untuk memperoleh kapabilitas dari perusahaan lain untuk memberikan pelayanan sesuai dengan keinginan perusahaan, saat ini maupun dimasa yang akan datang.

Didalam Laporan dari Komite atas Aspek Finansial dari Kesesuaian Perusahaan (Cadbury Report, 2002) membicarakan tentang kesesuaian sebagai pemikiran umumnya. Walaupun tujuan dari laporan tersebut adalah merupakan tujuan laporan keuangan dan audit, hal tersebut menyinggung pada konsep kesesuaian yang lebih luas. Dan mendefinisikan pelaksanaan kesesuaian sebagai pedoman dalam menjaga hubungan antara pimpinan perusahaan dan seluruh karyawannya, pemilik dan para pimpinan perusahaan dengan memberikan suatu gambaran melalui struktur sbb:

1. Adanya tujuan perusahaan yang jelas

2. Adanya metoda guna menerapkan tujuan yang harus ditentukan

3. Adanya pedoman pelaksanaan kesesuaian

Kesesuaian IT merupakan tanggung jawab dari dewan direktur dan para pimpinan eksekutif. Hal ini merupakan bagian yang tidak terpisahkan dengan kesesuaian perusahaan dan termasuk didalamnya kepemimpinan dan struktur organisasi dan suatu proses yang dapat memberikan kepastian bahwa IT dapat menopang dan memperluas strategi dan tujuan perusahaan.

Tujuan kesesuaian IT adalah untuk membantu secara langsung, dan menjamin bahwa pelaksanaan IT telah memenuhi tujuan sebagai berikut:

1. Agar IT dapat sejalan dengan perusahaan dan menjamin perolehan keuntungan bagi perusahaan

2. Agar IT dapat memungkinkan perusahaan memperoleh kesempatan untuk mengeklorasi dan memaksimalkan keuntungan

3. Agar sumber-sumber IT dapat digunakan secara bertanggung jawab

4. Agar resiko-resiko IT yang ditimbulkan dapat diatasi dengan baik

Contoh dari kesesuaian IT adalah pimpinan group akan melaporkan dan menerima perintah dari para menejer, dimana para menejer melaporkan kepada para pimpinan dan para pimpinan melaporkan kepada para direktur. Laporan tersebut membahas tentang tujuan, pencapaian tujuan, tidak pencapaian tujuan dan rekomendasi.

Proses kesesuaian dimulai dengan menentukan tujuan IT pada perusahaan, dengan memberikan panduan awal. Selanjutnya masuk kepada hal berikutnya yaitu pelaksanaan yang dapat diukur dan dibandingkan dengan tujuan, hasil dalam penjelasan kembali mengenai aktifitas yang diperlukan dan perubahan tujuan apabila diperlukan. Apabila pada awalnya tujuan perusahaan adalah merupakan tanggung jawab para direktur dan pelaksanaannya diukur berdasarkan manajemen yang berlaku, dapat diyakini bahwa mereka harus membuat suatu konsep sehingga tujuan yang ada dapat dicapai dan mengukur pelaksanaan tujuan dengan tepat. 


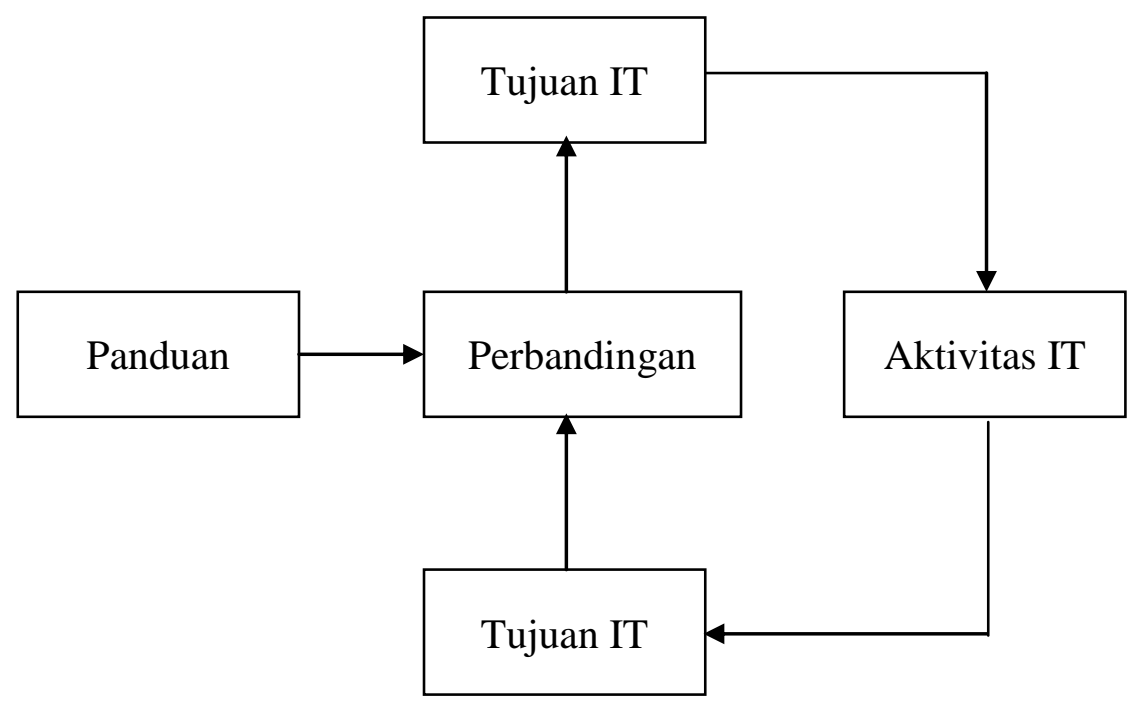

Gambar 2.1 Model Kesesuaian IT

Sebagai tanggapan atas perintah yang diterima, fungsi IT haruslah terfokus pada perealisasian keuntungan dengan cara peningkatan secara otomatis dan membuat perusahaan semakin efektif, dengan melalui pengurangan biaya dan menciptakan keseluruhan perusahaan menjadi semakin efisien, dan dalam mengatasi resiko (keamanan, kepercayaan dan pemenuhan).

\subsubsection{Mengapa Kesesuaian IT Penting?}

Penggunaan IT akan menjadi penggerak perekonomian yang penting diabad ke 21. IT telah menjadi salah satu persyaratan penting bagi kesuksesan perusahaan, dengan memberikan keuntungan yang kompetitif dan menawarkan cara peningkatan produktifitas hal ini akan menjadi sangat penting dimasa yang akan datang. Pengaruh keberhasilan IT mentransformasi perusahaan dan menciptakan keunggulan atas suatu produk dan jasa telah menjadi suatu kemampuan yang umum bagi perusahaan. IT merupakan hal yang mendasar bagi perusahaan guna menggali kemampuan hubungan konsumen dan manajemen, kenaikan transaksi secara global dan dematerialisasi, dan merupakan kunci guna mengingat dan menambah pengetahuan usaha.

Mengingat IT merupakan hal yang penting dalam membantu dan memungkinkan pencapaian tujuan perusahaan, kesesuaian IT yang effektif akan benar-benar memberikan keuntungan perusahaan, seperti reputasi, kepercayaan, produk yang unggul, ketepatan waktu pemasaran dan mengurangi pengeluaran, kesemuanya ini dapat meningkatkan keuntungan bagi para pemilik modal.

Ketika IT menjadi hal yang penting guna menyangga perusahaan dimana mungkin juga bukan merupakan sesuatu yang mewah dan digunakan untuk menjamin pelaksanaan usaha, adalah sama pentingnya guna pembangunan dan menginovasikan suatu usaha. Dengan fokus komersial yang ketat dapat merupakan tantangan masa depan namun demikian haruslah berhatihati karena IT juga membawa resiko. Jelaslah bahwa pada saat ini pelaksanaan usaha secara global, terikat dengan waktu, sistem dan jaringan yang ada merupakan beban pengeluaran yang besar yang harus ditanggung oleh perusahaan. Dalam beberapa industri, IT merupakan solusi yang kompetitif guna membedakan dan memberikan keuntungan kompetitif ketika perusahaan lainnya masih berputar pada masalah bagaimana dapat bertahan bukan hanya karena faktor 
keberuntungan. Kebutuhan dan resiko tersebut menjadikan beban bagi manajemen guna memaksimalkan IT secara lebih efektif dan transparan.

Oleh karenanya perlu ada tinjauan kembali tentang seberapa penting IT bagi perusahaan dan seberapa banyak kontribusi IT dalam pengambilan keputusan strategi perusahaan. Para pemimpin cenderung hanya sering melihat pada strategi usaha dan resiko yang ditimbulkan, dimana mungkin tidak menghasilkan keuntungan, namun demikian pada kenyataannya hal itu mencakup investasi yang besar dan resiko yang besar pula.

\subsubsection{Siapakah Yang Harus Memperhatikan?}

Kesesuaian IT menjadi tanggung jawab para pimpinan dan pemegang saham. Tanggung jawab itu dirumuskan menjadi sebuah panduan para pimpinan sebagai sistem kesesuaian internal. Hal ini dibuat karena sering terjadi perbedaan pada tingkatan tertentu dalam perusahaan. Melalui laporan tersebut para pemimpin mengetahui bahwa terdapat atau telah terjadi proses yang efektif dan tepat atau tidak terjadinya proses secara efektif. Disamping digunakan untuk memantau resiko dan meyakinkan bahwa sistem kesesuaian internal yang ada dilakukan secara efektif atau tidak berjalan secara efektif dalam mengurangi resiko pada tingkatan tertentu.

Dari penjelasan diatas, kesesuaian IT dilaksanakan secara intensif dilaksanakan para pimpinan dan manajemen eksekutif. Namun demikian, mengingat kompleksitas dan spesialisasi, tingkatan ini harus sejalan dengan tingkat kekuatan dari tingkat terendah dalam perusahaan guna memberikan informasi yang dibutuhkan dalam pembuatan keputusan dan mengevaluasi aktifitas yang dilakukan.

Guna memperoleh kesesuaian IT yang efektif dalam perusahaan, tingkatan yang terendah harus mengaplikasikan beberapa prinsip dalam menentukan tujuan, memberikan dan menentukan tujuan, dan menyiapkan dan mengevaluasi pelaksanaannya. Sebagai hasilnya, pengalaman yang baik dalam kesesuaian IT dibutuhkan untuk diaplikasikan didalam perusahaan.

\subsubsection{Apa Yang Dapat Mereka Lakukan?}

Tanggung jawab kesesuaian IT dari sisi pimpinan dalam hal panduan kesesuaian perusahaan. Panduan ini secara baik mencakup kesesuaian perusahaan yang memfokuskan pada hak-hak, peraturan, dan pelaporan yang tepat bagi para pemegang saham, lampiran dan transparansi serta tanggung jawab para pimpinan. Laporan tersebut kemudian disebut dengan panduan kesesuaian guna menjamin adanya panduan strategis bagi perusahaan yang mudah dipahami, untuk pemantauan manajemen yang efektif oleh para pemimpin, dan bagi para pemimpin agar dapat dipertanggung jawabkan kepada perusahaan dan para pemegang saham.

Salah satu tangung jawab para pemimpin, adalah meninjau dan membantu pembuatan strategi perusahaan, menentukan dan memantau perkembangan dari pelaksanaan tujuan oleh manajemen, dan meyakinkan integritas sistem perusahaan. Terpisah dari kenyataan bahwa kesesuaian IT ditujukan sebagaimana agenda strategis para pemimpin, pengamanan haruslah efektif, transparan and bertanggung jawab. Untuk itu para pimpinan harus terbuka atas tanggung jawabnya maupun manajemennya, dan harus memiliki sistem yang ditempatkan guna pelaksanaan tanggung jawab tersebut yang secara menyeluruh berhubungan dengan kesesuaian IT dan digunakan dalam setiap aktivitas perusahaan, manajemen teknologi sehubungan dengan resiko usaha dan pembuktian atas keuntungan yang diberikan melalui penggunaan IT dalam perusahaan. 


\subsubsection{Kebutuhan Kesesuaian Dalam Teknologi Informasi}

Dalam beberapa tahun terakhir, pada kenyataannya terdapat peningkatan kebutuhan atas referensi yang dapat memberikan gambaran mengenai keamanan dan kesesuaian dalam sistem IT. Suatu perusahaan yang berhasil membutuhkan suatu penghargaan dan pengertian dasar mengenai resiko dan penekanan sistem IT pada segala tingkatan dalam penentuan guna mencapai arah yang lebih efisien dan terkontrol.

Pimpinan harus dapat memutuskan alasan investasi untuk pengamanan dan kesesuaian dalam sistem IT dan bagaimana menyeimbangkan resiko dan kesesuaian investasi dalam situasi IT yang seringkali tidak dapat diduga. Sedangkan sistem informasi dalam rangka kesesuaian dan pengamanan membantu mengatasi resiko-resiko yang tidak dapat dihindarkan. Selain itu, pada tingkat tertentu, resiko tidak dapat diprediksi. Pada akhirnya, pimpinan harus menentukan tingkat resiko tertentu yang diterima apalagi berdasarkan biaya sehingga pimpinan harus mengambil keputusan yang sulit tersebut. Oleh karena itu pimpinan membutuhkan suatu gambaran yang jelas tentang pengamanan dan kesesuaian IT guna menjadi pembanding antara sistem yang ada saat ini dengan sistem IT yang direncanakan.

Sebagai bukti, terdapat peningkatan jumlah pengguna jasa IT, melalui penilaian dan pemeriksaan baik secara internal maupun melalui pihak ketiga, yang dapat mempengaruhi kesesuaian dan pengamanan yang telah ada. Namun demikian, pada saat ini dalam implementasi kesesuaian sistem informasi yang baik masih terdapat kerancuan antara perusahaan swasta, non government dan pemerintah.

Untuk pelaksanaan hal tersebut, manajemen harus dapat mengidentifikasikan hal-hal yang paling penting yang harus diprioritaskan dalam pelaksanaan, mengukur kemajuan dalam pencapaian tujuan dan menggolongkan seberapa baik proses IT yang dijalankan. Selain itu hal ini juga membutuhkan kemampuan untuk menilai tingkat kemandirian perusahaan melalui pembandingan dengan sesama industri yang berhasil dengan standar internasional. Untuk menunjang kebutuhan manajemen tersebut, Cobit telah mengidentifikasikan beberapa faktorfaktor keberhasilan yang kritikal, indikator dalam pencapaian tujuan, indikator dalam pelaksanaan dan penggabungan model yang telah sukses dalam penerapan sistem IT.

\subsection{Cobit (Control Objectives for Information and related Technology)}

Dewasa ini terdapat dua macam pengkualifikasian yang berbeda atas metode kesesuaian, yaitu: pengkualifikasian menggunakan "metode kesesuaian bisnis" dan "metode kesesuaian yang lebih terfokus pada IT" (IT Governance Institute, 2001). Cobit bertujuan untuk menjembatani perbedaan yang masih terdapat pada kedua metode tersebut. Namun demikian, Cobit berusaha tetap berada pada posisi manajemen yang komprehensif dan dioperasikan untuk tingkat yang lebih tinggi daripada standar sistem informasi manajemen. Oleh karena itu, Cobit merupakan metode untuk kesesuaian IT.

Dasar pemikiran konsep Cobit adalah kesesuaian melalui pendekatan dengan memperhatikan sistem informasi yang dibutuhkan guna menunjang tujuan usaha atau kebutuhan dan melalui sistem informasi yang merupakan hasil aplikasi penggabungan dari IT yang berhubungan dengan sumber informasi yang dibutuhkan untuk mengatur proses IT.

\subsection{Model Maturity}

Manajemen pada suatu perusahaan dan organisasi publik sering dimintakan untuk memecahkan masalah bisnis sehubungan dengan hal-hal yang menjadi penyebab terjadi 
pengeluaran dalan kesesuaian struktur informasi. Walaupun sebagian orang beranggapan bahwa hal tersebut tidaklah penting namun haruslah dipertimbangkan atau dipertanyakan, seperti

"Seberapa jauh implementasi sistem IT, apakah pengeluaran sebanding dengan keuntungan yang didapatkan?"

Untuk membantu manjawab pertanyaan diatas, dapat dibantu dengan pertanyaan lainnya, contohnya (IT Governance Institute, 2001)

"Standar apakah yang digunakan internasional dan bagaimana mengimplementasiannya?" atau

"Apakah yang dilakukan organisasi lain dan bagaimana cara kita melakukan penelitian sehubungan dengan hal yang dilakukan perusahaan lainnya?"

Pertanyaan tersebut merupakan beberapa contoh pertanyaan yang sering ditanyakan kepada manajemen. Manajemen akan sulit memberikan jawaban yang tepat jikalau tidak mempunyai pengalaman ataupun data-data. Pengalaman atau data-data tersebut didapatkan dari evaluasi yang dilakukan perusahaan.

Sehubungan dengan pernyataan diatas, manajemen IT diharapkan secara berkala mengevaluasi proses struktur informasi perusahaan yang ada. Untuk itu dapat mempergunakan Cobit dalam hal evaluasi dan kesesuaian serta dibutuhkan beberapa hal:

1. Suatu ukuran yang relatif mengenai dimana letak organisasi.

2. Cara efisien yang diambil untuk kesesuaian.

3. Alat untuk mengukur kemajuan pencapaian tujuan organisasi

Cobit mempunyai 34 proses dari 4 proses utama yang dapat digunakan dalam kesesuaian IT.

Pendekatan atas model guna kesesuaian IT dapat meliputi pembuatan metode penilaian sehingga organisasi dapat menentukan tingkatannya. Dari penentuan tingkatan tersebut, perusahaan dapat secara membuat target baru yang ingin dicapai serta sejalan dengan harapan dan tujuan perusahaan.

Pendekatan Cobit ini adalah panduan umum yang menjadikan tujuan manajemen IT dengan penerapan praktis dan mudah dipahami.

Maturity Model adalah cara untuk mengukur seberapa baiknya kemajuan dari proses manajemen IT pada perusahaan. Pengukuran ini dengan menggunakan skala atau batasan (0 s.d. 5) sebagai contoh praktis dalam menentukan tingkatan kemampuan manajemen IT pada setiap tingkat kemampuan. Dari tingkatan perusahaan tersebut dibandingkan dengan target perusahaan dan referensi Maturity Model Cobit serta kenyataan di lapangan.

Maturity Model yang dibuat dengan kualitatif model akan menghasilkan masukan sebagai berikut:

1. Mengerti dan memperhatikan resiko dan masalah kesesuaian.

2. Pelatihan dan pengkomunikasian yang diterapkan atas masalah yang ada.

3. Teknik dan otomatisasi guna membuat proses lebih efektif dan efisien.

4. Tingkat pemenuhan atas kebijakan internal, perundang-undangan dan peraturan.

\section{METODOLOGI PENELITIAN}

\subsection{Kerangka Pikir}

Kerangka pikir merupakan penjelasan tentang keseluruhan kegiatan penelitian dan masalah yang akan dipecahkan serta variable-variabel apa yang bisa memecahkan masalah tersebut. Kerangka pikir dalam penelitian analisis dan pengukuran IT Aligment adalah sebagai berikut : 


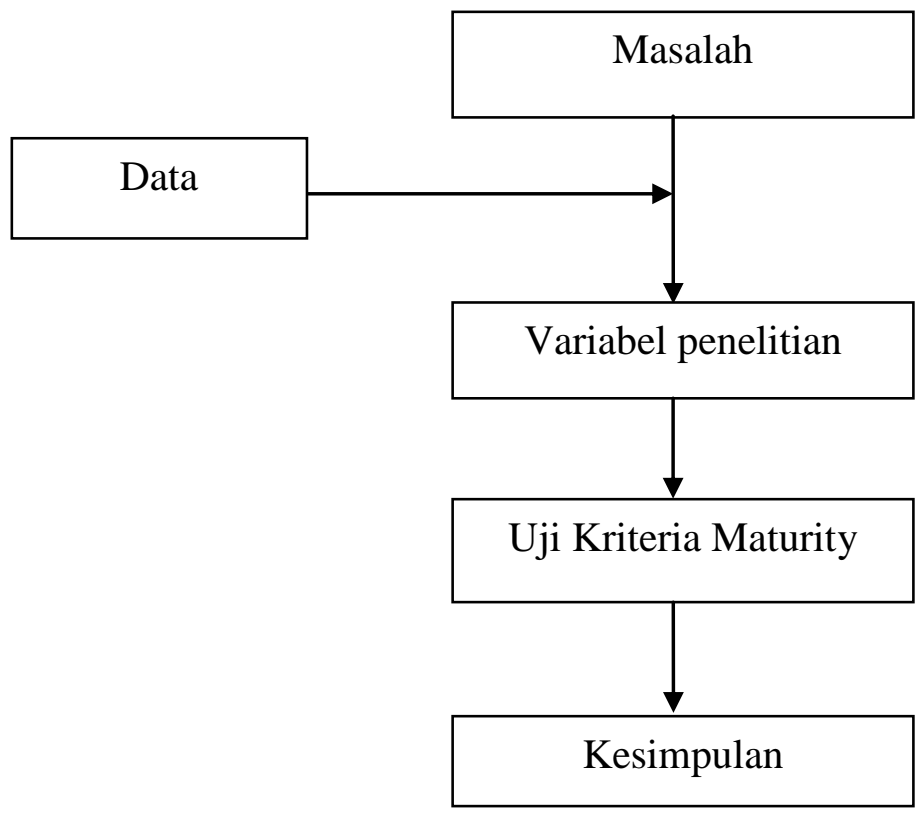

\section{Gambar 3.1 Kerangka Pikir Penelitian}

Pada gambar 3.1 di atas dapat dijelaskan bahwa masalah dalam hal ini analisis dan pengukuran teknologi informasi dapat dipecahkan atau diberikan solusi dengan memakai model penelitian kualitatiff sehingga menggunakan uji criteria maturity untuk mengolah data. Penelitian ini di mulai bulan Januari 2014 sampai Juni 2014 di PT. William Makmur Perkasa Manado.Penelitian di mulai dengan pembuatan kuesioner, testing kuesioner, pengumpulan data, analisa data dan pembuatan report dari hasil penelitian.

\subsection{Tempat dan Waktu Penelitian}

Penelitian dilakukan pada PT William Makmur Perkasa yang bergerak pada bidang rental alat berat. Perusahaan rental alat berat ini memiliki jumlah karyawan seluruhnya sebanyak 68 orang (per Juni 2014).

Untuk mendukung penelitian ini, survey dilakukan pada bulan Pebruari 2014 dengan cara menyebarkan kuesioner serta mengambil sampel pada tingkat level manajemen.

Sebelum kuesioner ini dibagikan, para responden telah diberitahukan mengenai maksud diadakannya penelitian ini.

Identitas dari semua responden dirahasiakan dan dijamin kerahasiaannya agar responden lebih obyektif dalam menjawab semua pertanyaan yang ada dalam kuesioner yang dibagikan.

Sampel yang diambil dari responden manajemen level menengah dan atas, yaitu Supervisor, Manager dan General Manager.

Responden ini diberikan kuesioner pemeriksaan awal (pre-audit). Selanjutnya dibandingkan dengan pemeriksaan di lapangan (pada status sistem pada saat ini).

\subsection{Variabel Penelitian}

Varibel penelitian sebagai berikut:

1. Perencanaan dan Pengorganisasian adalah penentuan tentang strategi dan perencanaan, serta kontribusi IT guna pemenuhan sasaran obyektif. Selanjutnya, 
realisasi dari strategi membutuhkan perencanaan, komunikasi, dan pengelolaan untuk keperluan perspektif yang berbeda. Pada akhirnya, suatu pengorganisasian dan teknologi informasi yang tepat haruslah ditentukan dengan cermat.

2. Pengalihan dan Implementasi adalah penentuan strategi, pemecahan masalah atau solusi, pengembangan, pengimplemetasian dan pengintegrasian IT didalam suatu proses bisnis. Selain itu, bagian perubahan dan pemeliharaan dari sistem yang berjalan merupakan bagian pengalihan dari implementasi ini sehingga perubahan dan pemeliharaan sesuai dengan kebutuhan sistem dan proses usaha.

3. Distribusi dan Penunjang menintikberatkan pada pelaksanaan pendistribusian jasa yang meliputi aspek keamanan operasi secara tradisional sampai dengan pelatihan dan secara berkesinambungan harus dapat menunjang proses baru yang dibentuk atau dibangun. Pada bagian ini termasuk pula bagian prosesing data beserta pemantauan atau kontrol dari aplikasi data tersebut.

4. Pemantauan adalah pengamatan atas keseluruhan proses IT secara berkala untuk mempertahankan kualitas dan proforma sesuai standar pemantauan. Pemantauan ini ditujukan bagi manajemen sebagai serana kesesuaian organisasi yang independen baik secara internal maupun eksternal atau melalui sumber-sumber informasi lainnya.

Dari keempat variabel tersebut diatas hanya variabel pertama tentang Perencanaan dan Pengorganisasian yang dipilih untuk diteliti pada PT. William Makmur Perkasa tersebut. Hal ini dikarenakan variabel pertama berkenaan dengan dokumentasi dan tidak memakan waktu dalam penelitian dan penulisan jurnal ini serta sesuai dengan saran dari PT William Makmur Perkasa.

\section{Perencanaan dan Pengorganisasian}

1. Penentuan Perencanaan Strategis IT bertujuan untuk memberikan keseimbangan yang optimal dalam memenuhi tuntutan dalam perolehan IT dan bisnis IT, demikian pula dalam kesinambungannya kedepan

2. Penentuan Arsitektur Informasi bertujuan untuk memenuhi arsitektur informasi dalam mengoptimalkan sistem informasi perusahaan.

3. Pemilihan Arah Perkembangan Teknologi bertujuan untuk mendapatkan kesempatan dalam memperoleh keuntungan dan memungkinkan penggabungan teknologi guna pelaksanaan strategi bisnis.

4. Penentuan Hubungan dan Struktur Organisasi IT bertujuan untuk menentukan sistem IT yang tepat.

5. Pengelolaan Investasi IT bertujuan untuk menjamin bahwa rencana pembiayaan dan operasional budget yang dibuat akan memperoleh persetujuan.

6. Pengkomunikasian Tujuan dan Sasaran Manajemen bertujuan untuk menjamin bahwa pemakai dapat mengerti dan mengetahui tujuan dan sasaran manajemen.

7. Pengelolaan Sumber Daya Manusia bertujuan untuk memperoleh kemampuan dalam mengelola tenaga kerja yang kompeten dan memiliki motivasi guna memaksimalkan kontribusi karyawan dalam proses IT.

8. Kepastian Kebutuhan sesuai dengan Permintaan Eksternal bertujuan untuk memenuhi kewajiban perundang-undangan, peraturan dan kewajiban kontrak lainnya.

9. Perkiraan Resiko bertujuan untuk membantu manajemen dalam mengambil keputusan melalui pencapaian tujuan IT dan memberikan respon bagaimana 
mengurangi kompleksitas dan meningkatkan pencapaian tujuan serta mengidentifikasikan faktor keputusan yang penting.

10. Pengelolaan Proyek-proyek bertujuan untuk penentuan skala prioritas dalam pengiriman data yang tepat waktu dan sesuai dengan anggaran.

11. Pengelolaan Kualitas bertujuan untuk memenuhi permintaan IT.

\subsection{Kriteria}

Kriteria penilaian didasarkan pada analisis "Maturity Model" COBIT guna manajemen IT dapat mengukur kematangan dalam pengelolaan dan efisiensi IT pada saat ini.

Maturity Model ini memberikan 3 masukan, yaitu:

1. memberikan masukan pengukuran keberadaan IT pada saat ini.

2. memberikan masukan arah efisiensi yang diperlukan

3. sebagai alat pembanding antara keberadaan IT pada saat ini dengan tujuan dan harapan perusahaan.

\section{Uji Kriteria Maturity ("UkM")} berikut:

Proses pengujian ini menggunakan UkM ini menggunakan skala Likert, $0-5$, sebagai

0 - Tidak Ada/Non-Existent, berarti proses manajemen belum diaplikasikan sama sekali.

1 - Permulaan/Initial, berarti proses masih bersifat sementara dan belum diproses.

2 - Pengulangan/Repetable, berarti proses mengikuti pola yang standar.

3 - Penentuan/Defined, berarti proses terdokumentasi dan dapat didiskusikan.

4 - Pengelolaan/Managed, berarti proses dapat termonitor dan diukur.

5 - Optimaliasasi/Optimised, berarti pengalaman terbaik yang digunakan dan secara otomatis.

Dari uji kriteria diatas, peneliti dapat memberikan masukan tingkatan manajemen IT pada saat ini lalu dibandingkan dengan referensi Cobit dan kenyataan di lapangan.

\section{HASIL DAN PEMBAHASAN}

\section{Pengolahan Data}

\subsubsection{Profil Responden}

Responden terdiri 6 responden dengan klasifikasi responden manajemen level menengah dan atas, yaitu Supervisor, Manager dan General Manager (lihat Tabel 4.1). Ke-6 responden ini adalah pengambilan keputusan di departemen yang ada di PT Willem Makmur Perkasa tentang kinerja perusahaan sehingga dapat dikatakan bahwa ke-6 responden mewakili PT William Makmur secara keseluruhan. 
Tabel 4.1 Tabel Profil Responden

\begin{tabular}{|l|c|c|}
\hline & Jumlah & $\%$ \\
\hline Usia & & \\
$<25$ & 2 & 33,33 \\
$25-34$ & 2 & 33,33 \\
$35-44$ & 2 & 33,33 \\
\hline$>45$ & 3 & \\
\hline Jenis Kelamin & 3 & 50 \\
Pria & & \\
Wanita & & \\
\hline Pendidikan & 2 & 33,33 \\
SMA & 3 & 50 \\
Diploma & 1 & 16,67 \\
Sarjana & & \\
S2 & 4 & 66,66 \\
Lainnya & 1 & 16,67 \\
\hline Pekerjaan & 1 & 16,67 \\
Director/ Manager & & \\
Deputi Manager & 1 & 16,66 \\
Supervisor & & \\
\hline Lama Bekerja & & \\
$<3$ thn & 3 & 50 \\
3 s.d. <6 thn & 1 & 16,67 \\
6 s.d. <9 thn & 1 & 16,67 \\
\hline 9 s.d. < 12 thn & & \\
12 s.d. < 15 thn & & \\
15 s.d. < 18 thn & & \\
\hline
\end{tabular}

\subsubsection{Data Keseluruhan}

Data keseluruhan ini ada data tentang level marutity pada Perusahaan PT William Makmur Perkasa setelah diadakan analisa dan perhitungan dengan menggunakan cara perhitungan COBIT. Sebagai contoh, Penentuan Perencaan Strategi IT, level maturitynya adalah 3,585, berarti bahwa pengambilan keputusan untuk perencanaan strategis IT dilakukan oleh top manajemen, perencanaan diperbaharui oleh manajemen IT sesuai dengan perubahan teknologi yang disesuaikan dengan tujuan perusahaan serta memperhitungkan faktor resiko, diharapkan perusahaan menetapkan prosedur baku untuk perencanaan jangka pendek dan jangka panjang, pemonitoran pelaksanaan, operasional dan dokumentasi rencana strategis IT secara berkala. Prosedur baku adalah prosedur yang sesuai dengan standar internasional yang berlaku dan sebaiknya manajemen IT membuat atau mengikuti pelatihan tentang perencanaan strategis IT (lihat Tabel 4.4). 
Tabel 4.2 Data Keseluruhan

\begin{tabular}{|c|c|c|}
\hline No & PERENCANAAN DAN PENGORGANISASIAN & MATURITY LEVEL \\
\hline 1 & Penentuan Perencanaan Strategis IT & 3,585 \\
\hline 2 & Penentuan Arsitektur Informasi & 3,833 \\
\hline 3 & Pemilihan Arah Perkembangan Teknologi & 3,857 \\
\hline 4 & Penentuan Hubungan dan Struktur Organisasi IT & 4,000 \\
\hline 5 & Pengelolaan Investasi IT & 3,500 \\
\hline 6 & $\begin{array}{l}\text { Pengkomunikasian Tujuan dan Sasaran } \\
\text { Manajemen }\end{array}$ & 3,267 \\
\hline 7 & Pengelolaan Sumber Daya Manusia & 3,465 \\
\hline 8 & $\begin{array}{l}\text { Kepastian Kebutuhan sesuai dengan Permintaan } \\
\text { Eksternal }\end{array}$ & 2,947 \\
\hline 9 & Perkiraan Resiko & 3,714 \\
\hline 10 & Pengelolaan Proyek-proyek & 3,370 \\
\hline 11 & Pengelolaan Kualitas & 3,488 \\
\hline \multicolumn{2}{|r|}{ Rata-rata } & 3,548 \\
\hline
\end{tabular}

Dari hasil data diatas, rata-rata maturity model PT William Makmur Perkasa adalah 3,548. Angka ini menunjukkan bahwa standar PT William Makmur Perkasa lebih baik dari standar internasional, yaitu 2.500 dan kesesuaian dengan tujuan perusahaan sudah mendekati yang diharapkan.

\subsection{Pembahasan}

\subsubsection{IT Maturity Model}

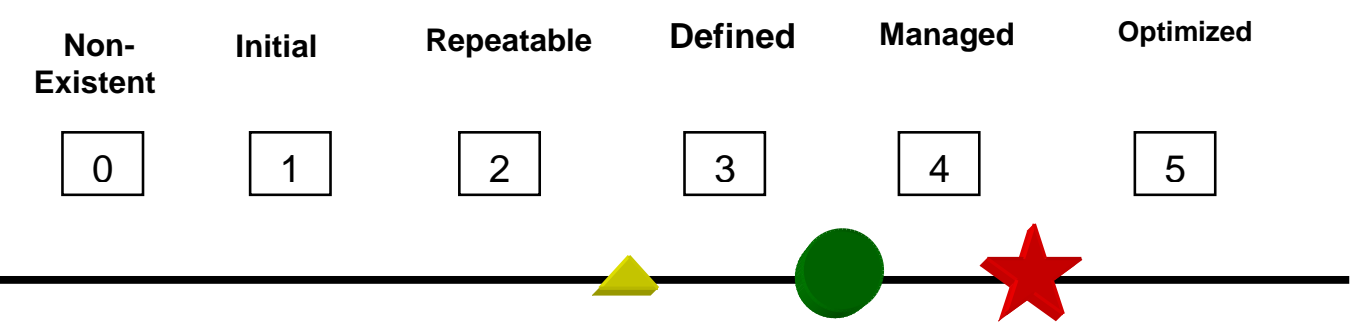

\section{Legend for symbols used}

Current status of the organization

International Standard

Organization's strategy for improvement
- where the organization wants to be

\section{Legend for rankings used}

0 - Management processes are not applied at all 1 - Processes are ad hoc and disorganized

2 - Processes follow a regular pattern

3- processes are documented and communicated

4 - Processes are monitored and measured

5 - Best practices are followed and automated

\section{Gambar 4.1 Maturity Model PT William Makmur Perkasa}

Dari hasil data primer diatas, rata-rata maturity model PT William Makmur Perkasa adalah 3,548. Angka ini menunjukkan bahwa standar perusahaan lebih baik dari standar 
internasional, yaitu 2.500 dan kesesuaian dengan tujuan perusahaan sudah mendekati yang diharapkan.

\subsubsection{Analisis IT Maturity Model}

Tabel 4.3 dibawah ini menggambarkan bahwa Analisa Perbandingan antara keadaan saat ini dengan target PT William Makmur Perkasa dalam beberapa tahun mendatang. Analisa ini memperjelas tentang kesesuian antara perencanaan dan pengorganisasi IT dengan tujuan perusahaan, sebagai contoh Penentuan Perencanaan Strategis IT (tingkat maturity saat ini adalah 3,585 ) dan target yang ingin dicapai adalah 5,000, bahwa penentuan perencanaan strategis IT merupakan satu bagian yang tak terpisahkan dengan perencanaan strategis IT secara keseluruhan baik perencanaan jangka pendek dan jangka panjang, dan tidak seperti pernyataan tentang kriteria 0, COBIT, bahwa perencanaan strategis IT tidak dilaksanakan dimana manajemen tidak sadar akan kebutuhan perencanaan strategis IT guna mencapai tujuan perusahaan. Disamping itu pula, departemen IT telah menjalankan misinya sebagai pemberi pemecahan masalah tentang sistem informasi dan memberikan pelayanan kepada pelanggan, yaitu konsulan, pengacara, paralegal dan pengguna komputer lainnya.

Tabel 4.3. Tingkat maturity-saat ini dan target

\begin{tabular}{|c|c|c|c|}
\hline \multirow{2}{*}{ No } & \multirow{2}{*}{ Perencanaan dan Pengorganisasian } & \multicolumn{2}{|c|}{ Tingkat Maturity } \\
\hline & & Saat Ini & Target \\
\hline 1 & Penentuan Perencanaan Strategis IT & 3,585 & 5,000 \\
\hline 2 & Penentuan Arsitektur Informasi & 3,833 & 5,000 \\
\hline 3 & Pemilihan Arah Perkembangan Teknologi & 3,857 & 4,000 \\
\hline 4 & $\begin{array}{l}\text { Penentuan Hubungan dan Struktur Organisasi } \\
\text { IT }\end{array}$ & 4,000 & 5,000 \\
\hline 5 & Pengelolaan Investasi IT & 3,500 & 4,000 \\
\hline 6 & $\begin{array}{l}\text { Pengkomunikasian Tujuan dan Sasaran } \\
\text { Manajemen }\end{array}$ & 3,267 & 4,000 \\
\hline 7 & Pengelolaan Sumber Daya Manusia & 3,465 & 4,000 \\
\hline 8 & $\begin{array}{l}\text { Kepastian Kebutuhan sesuai dengan Permintaan } \\
\text { Eksternal }\end{array}$ & 2,947 & 4,000 \\
\hline 9 & Perkiraan Resiko & 3,714 & 5,000 \\
\hline 10 & Pengelolaan Proyek-proyek & 3,370 & 4,000 \\
\hline 11 & Pengelolaan Kualitas & 3,488 & 4,000 \\
\hline & Rata-rata & 3,548 & 4,364 \\
\hline
\end{tabular}

Tabel 4.4. Strategi PT. William Makmur Perkasa

\begin{tabular}{|c|c|c|c|c|}
\hline No & $\begin{array}{l}\text { Perencanaan \& } \\
\text { Pengorganisasian }\end{array}$ & Saat ini & $\begin{array}{c}\text { Target-Rekomendasi } \\
\text { Cobit }\end{array}$ & Strategi \\
\hline 1 & $\begin{array}{l}\text { Penentuan } \\
\text { Perecanaan } \\
\text { strategi IT }\end{array}$ & $\begin{array}{l}\text { Data Primer: } \\
\text { * PT WMP menyadari } \\
\text { pentingnya } \\
\text { perencanaan strategi IT } \\
\text { baik untuk jangka } \\
\text { panjang maupun }\end{array}$ & $\begin{array}{l}\text { *Pengoptimalisasian } \\
\text { perencanaan strategis } \\
\text { IT adalah suatu } \\
\text { pendokumentasian } \\
\text { proses yang berjalan } \\
\text { secara } \\
\text { berkesimnambungan }\end{array}$ & $\begin{array}{l}\text { *Pengambilan } \\
\text { keputusan untuk } \\
\text { perencanaan } \\
\text { strategis IT } \\
\text { dilakukan oleh } \\
\text { top manajemen. }\end{array}$ \\
\hline
\end{tabular}




\begin{tabular}{|c|c|c|c|c|}
\hline No & $\begin{array}{c}\text { Perencanaan \& } \\
\text { Pengorganisasian }\end{array}$ & Saat ini & $\begin{array}{c}\text { Target-Rekomendasi } \\
\text { Cobit }\end{array}$ & Strategi \\
\hline & & 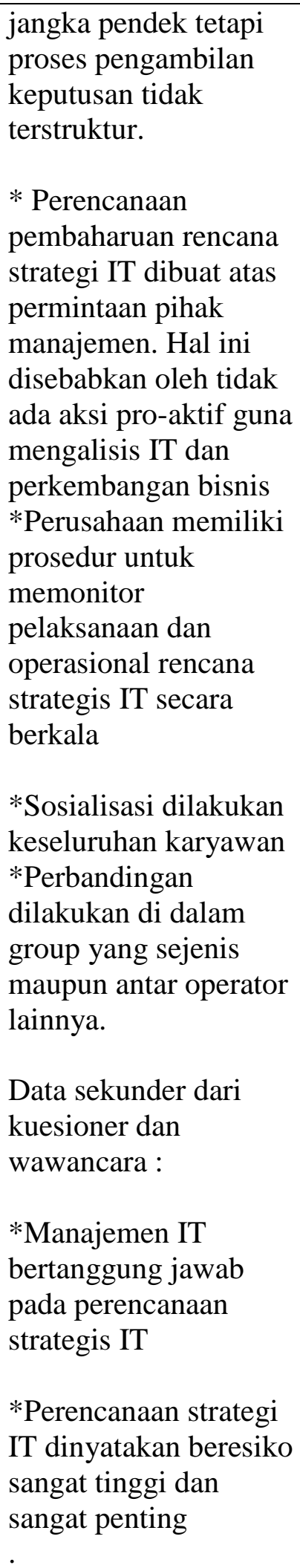 & 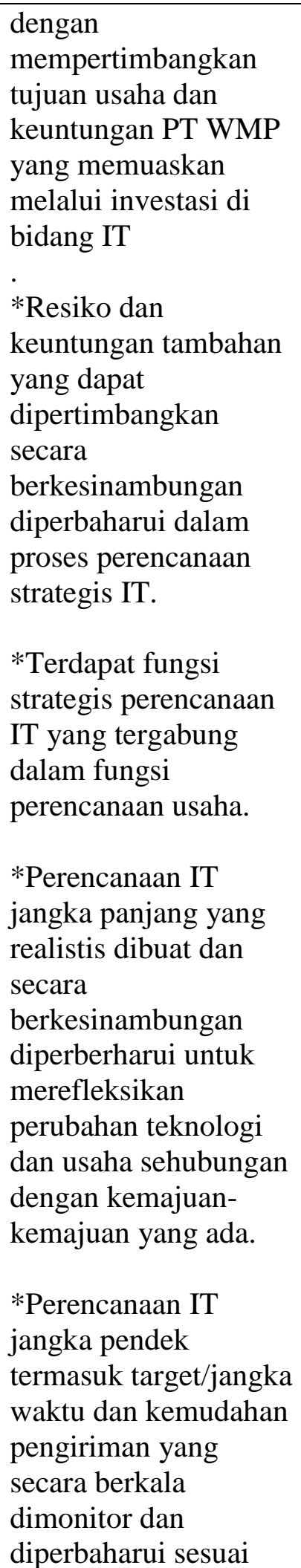 & $\begin{array}{l}\text { *Perencanaan } \\
\text { diperbaharui oleh } \\
\text { manajemen IT } \\
\text { sesuai dengan } \\
\text { perubahan } \\
\text { teknologi yang } \\
\text { disesuaikan } \\
\text { dengan tujuan } \\
\text { perusahaan serta } \\
\text { memperhitungkan } \\
\text { factor resiko } \\
\text { * } \\
\text { *PT WMP } \\
\text { menetapkan } \\
\text { prosedur baku } \\
\text { untuk } \\
\text { perencanaan } \\
\text { jangka pendek } \\
\text { dan jangka } \\
\text { panjang, } \\
\text { pemonitoran } \\
\text { pelaksanaan, } \\
\text { operasional dan } \\
\text { dokumentasi } \\
\text { rencana strategis } \\
\text { IT secara berkala. } \\
\text { Prosedur baku } \\
\text { adalah prosedur } \\
\text { yang sesuai } \\
\text { dengan standar } \\
\text { internasional } \\
\text { yang berlaku. } \\
\text { *Sebaiknya } \\
\text { manajemen IT } \\
\text { membuat atau } \\
\text { mengikuti } \\
\text { pelatihan tentang } \\
\text { perencanaan } \\
\text { strategi IT. }\end{array}$ \\
\hline
\end{tabular}




\begin{tabular}{|c|c|c|c|c|}
\hline No & $\begin{array}{c}\text { Perencanaan \& } \\
\text { Pengorganisasian }\end{array}$ & Saat ini & $\begin{array}{c}\text { Target-Rekomendasi } \\
\text { Cobit }\end{array}$ & Strategi \\
\hline & & $\begin{array}{l}\text { *Kemampuan dari } \\
\text { manajemen IT dalam } \\
\text { merencanakan masih } \\
\text { dianggap kurang. } \\
\text { *Hasil dari Evaluasi } \\
\text { dan dokumnentasi } \\
\text { yang dilaksanakan } \\
\text { manajemen IT } \\
\text { dianggap sedang. }\end{array}$ & $\begin{array}{l}\text { dengan perubahan } \\
\text { yang timbul. } \\
\text { *Perbandingan antara } \\
\text { mudah dimengerti dan } \\
\text { normal industry yang } \\
\text { terpercaya adalah } \\
\text { proses penentuan yang } \\
\text { baik dan terintegrasi } \\
\text { dengan strategi proses } \\
\text { formulasi. }\end{array}$ & \\
\hline 2 & $\begin{array}{l}\text { Penentuan } \\
\text { Arsitektur } \\
\text { informasi }\end{array}$ & $\begin{array}{l}\text { Data Primer : } \\
\text { *PT WMP memilik } \\
\text { arsitektur system IT. } \\
\text { *PT WMP mememiliki } \\
\text { prosedur pembuatan } \\
\text { arsitektur system IT } \\
\text { yang standard an } \\
\text { terdokumentasi. } \\
\text { *PT WMP sudah } \\
\text { menerapkan system } \\
\text { otomatisasi yang } \\
\text { belum seluruhnya } \\
\text { terintegrasi di } \\
\text { perusahaan. } \\
\text { *Karyawan IT } \\
\text { memiliki } \\
\text { keahlian/kemampuan } \\
\text { tersebut dimiliki } \\
\text { dengan cara belajar } \\
\text { sendiri (pelatihan } \\
\text { informal). } \\
\text { *Model arsitektur IT } \\
\text { PT WMP terus akan } \\
\text { dikembangkan sesuai } \\
\text { kondisi PT WMP. } \\
\text { Data sekunder : } \\
\text { *Manajemen IT }\end{array}$ & $\begin{array}{l}\text { *Pengoptimalisasian } \\
\text { arsitektur informasi } \\
\text { secara } \\
\text { berkesinambungan } \\
\text { memperkuat semua } \\
\text { tingkatan dan } \\
\text { keuntungannya untuk } \\
\text { usaha dapat } \\
\text { ditekankan. } \\
\text { *Tenaga IT memiliki } \\
\text { kemampuan dan } \\
\text { pengalaman yang } \\
\text { cukup untuk } \\
\text { membangun dan } \\
\text { menjaga kesehatan dan } \\
\text { arsitektur informasi } \\
\text { yang responsive yang } \\
\text { dapat merefleksikan } \\
\text { setiap permintaan } \\
\text { usaha } \\
\text { * Informasi yang } \\
\text { tersedia melalui } \\
\text { arsitektur informasi } \\
\text { diterapkan secara } \\
\text { berkesinambungan dan } \\
\text { signifikan. Penerapan } \\
\text { yang signifikan } \\
\text { menghasilkan } \\
\text { pengalaman terbaik } \\
\text { dalam pembuatan dan } \\
\text { perawatan arsitektur }\end{array}$ & $\begin{array}{l}\text { *Perusahaan } \\
\text { menetapkan } \\
\text { prosedur baku } \\
\text { untuk } \\
\text { perencanaan } \\
\text { jangka pendek } \\
\text { dan jangka } \\
\text { panjang, } \\
\text { pemonitoran } \\
\text { pelaksanaan, } \\
\text { operasional dan } \\
\text { dokumentasi } \\
\text { rencana strategis } \\
\text { IT secara berkala. } \\
\text { Prosedur baku } \\
\text { adalah prosedur } \\
\text { yang sesuai } \\
\text { dengan standar } \\
\text { internasional } \\
\text { yang berlaku. } \\
\text { *Prosedur baku } \\
\text { tersebut } \\
\text { digunakan untuk } \\
\text { mengevaluasian } \\
\text { arsitektur system } \\
\text { IT secara berkala. } \\
\text { *Disamping itu, } \\
\text { perusahaan } \\
\text { memberikan } \\
\text { pelatihan formal } \\
\text { kepada karyawan } \\
\text { IT guna peng } \\
\text { optimalisasian }\end{array}$ \\
\hline
\end{tabular}




\begin{tabular}{|c|c|c|c|c|}
\hline No & $\begin{array}{c}\text { Perencanaan \& } \\
\text { Pengorganisasian }\end{array}$ & Saat ini & $\begin{array}{c}\text { Target-Rekomendasi } \\
\text { Cobit }\end{array}$ & Strategi \\
\hline & & $\begin{array}{l}\text { bertanggung jawab } \\
\text { pada perencanaan } \\
\text { arsiktur informasi. } \\
\text { *Perencanaan } \\
\text { arsitektur informasi } \\
\text { dinyatakan beresiko } \\
\text { tinggi dan penting. } \\
\text { *Kemampuan dari } \\
\text { manajemen IT dalam } \\
\text { merencanakan } \\
\text { arsitektur informasi } \\
\text { dianggap sedang } \\
\text { mendekati baik. } \\
\text { *Evaluasi dari } \\
\text { arsitektur kurang dan } \\
\text { dokumentasi sudah } \\
\text { dilaksanakan. }\end{array}$ & $\begin{array}{l}\text { informasi termasuk } \\
\text { proses perkembangan } \\
\text { secara berkala. } \\
\text { * Strategi pembaharuan } \\
\text { informasi melalui bank } \\
\text { data dan sumber data } \\
\text { telah ditentukan. } \\
\text { Arsiktur informasi } \\
\text { secara berkala } \\
\text { mengalami kemajuan } \\
\text { dengan } \\
\text { mempertimbangkan } \\
\text { informasi non } \\
\text { tradisional dalam } \\
\text { proses, organisasi dan } \\
\text { system. }\end{array}$ & $\begin{array}{l}\text { arsitektur } \\
\text { informasi dan } \\
\text { bukan melalui } \\
\text { pelatihan } \\
\text { informal seperti } \\
\text { yang telah } \\
\text { dilakukan. }\end{array}$ \\
\hline 3 & $\begin{array}{l}\text { Pemilihan arah } \\
\text { perkembangan } \\
\text { teknologi }\end{array}$ & $\begin{array}{l}\text { Data Primer: } \\
\text { *PT. WMP belum } \\
\text { memiliki program } \\
\text { pelatihan untuk } \\
\text { melakukan riset IT. } \\
\text { *PT. WMP memiliki } \\
\text { rencana perkembangan } \\
\text { teknologi yang } \\
\text { terdokumentasi yang } \\
\text { sejalan dengan strategi } \\
\text { PT. WMP walaupun } \\
\text { belum konsisten. } \\
\text { *PT. WMP memantau } \\
\text { perkembangan } \\
\text { teknologi dan } \\
\text { melakukan } \\
\text { perbandingan terhadap } \\
\text { industry sejenis. } \\
\text { *Arah perkembangan } \\
\text { teknologi PT. WMP } \\
\text { belum didasari oleh } \\
\text { perkembangan industry } \\
\text { dan standar } \\
\text { international, tapi lebih }\end{array}$ & $\begin{array}{l}\text { *Manajemen dan } \\
\text { pengukuran tenaga IT } \\
\text { yang memiliki } \\
\text { pengalaman dan } \\
\text { kemampuan yang } \\
\text { dibutuhkan untuk } \\
\text { pembangunan } \\
\text { perencanaan teknologi } \\
\text { infrastruktur. } \\
\text { *Terdapat pelatihan } \\
\text { formal dan special } \\
\text { untuk riset teknologi. } \\
\text { Dampak potensial dari } \\
\text { perubahan dan } \\
\text { penggabungan } \\
\text { teknologi } \\
\text { diperhitungkan dan } \\
\text { terdokumentasi. } \\
\text { *Pimpinan dapat } \\
\text { mengidentifikasikan } \\
\text { deviasi dari rencana } \\
\text { dan pengantisipasian } \\
\text { masalah. } \\
\text { *Tanggung jawab atas }\end{array}$ & $\begin{array}{l}\text { *Sesuai dengan } \\
\text { pembahasan point } \\
1 \text { PT. WMP } \\
\text { menetapkan } \\
\text { prosedur baku. } \\
\text { *Prosedur baku } \\
\text { tersebut } \\
\text { digunakan untuk } \\
\text { mengevaluasi dan } \\
\text { menganalisa } \\
\text { perkembangan } \\
\text { teknologi secara } \\
\text { berkala sehingga } \\
\text { in konsistensi } \\
\text { tidak ter jadi lagi } \\
\text { *PT. WMP } \\
\text { melaksanakan } \\
\text { program pelatihan } \\
\text { formal untuk } \\
\text { meningkatkan } \\
\text { kualitas karyawan } \\
\text { IT. }\end{array}$ \\
\hline
\end{tabular}




\begin{tabular}{|c|c|c|c|c|}
\hline No & $\begin{array}{l}\text { Perencanaan \& } \\
\text { Pengorganisasian }\end{array}$ & Saat ini & $\begin{array}{c}\text { Target-Rekomendasi } \\
\text { Cobit }\end{array}$ & Strategi \\
\hline & & $\begin{array}{l}\text { dilandasi kebutuhan } \\
\text { PT.WMP } \\
\text { *Karyawan IT } \\
\text { memiliki kemampuan } \\
\text { untuk mengembangkan } \\
\text { rencana infrastruktur } \\
\text { IT. } \\
\text { Data sekunder dari } \\
\text { kuessioner dan } \\
\text { wawancara : } \\
\text { *Manajemen IT } \\
\text { bertanggung jawab } \\
\text { pada perencanaan arah } \\
\text { perkembangan } \\
\text { teknologi. } \\
\text { *Perencanaan arah } \\
\text { perkembangan } \\
\text { teknologi dinyatakan } \\
\text { beresiko tinggi dan } \\
\text { penting. } \\
\text { *Kemampuan dari } \\
\text { manajemen IT dalam } \\
\text { merencanakan arah } \\
\text { perkembangan } \\
\text { teknologi dianggap } \\
\text { sedang mendekati baik. } \\
\text { *Evaluasi dari } \\
\text { arsitektur kurang dan } \\
\text { dokumentasi sudah } \\
\text { dilaksanakan. }\end{array}$ & $\begin{array}{l}\text { pembuatan dan } \\
\text { perawatan dari } \\
\text { perencanaan teknologi } \\
\text { infrastruktur telah } \\
\text { ditentukan. } \\
\text { *Proses yang sulit dan } \\
\text { responsive terhadap } \\
\text { perubahan. } \\
\text { Pengalaman internal } \\
\text { terbaik telah } \\
\text { digabungkan ke dalam } \\
\text { proses. } \\
\text { *Strategi HRD sejalan } \\
\text { dengan arah teknologi } \\
\text { guna menyakinkan } \\
\text { bahwa tenaga-tenaga } \\
\text { IT yang ada dapat } \\
\text { mengatasi perubahan- } \\
\text { perubahan IT. } \\
\text { *Perencanaan migrasi } \\
\text { untuk pengenalan } \\
\text { teknologi baru telah } \\
\text { dilaksanakan. } \\
\text { *Outsourcing dan } \\
\text { kerjasama telah } \\
\text { dilakukan untuk dapat } \\
\text { mengakses } \\
\text { kemampuan dan } \\
\text { pengalaman yang } \\
\text { cukup. }\end{array}$ & \\
\hline 4 & $\begin{array}{l}\text { Penentuan } \\
\text { hubungan dan } \\
\text { struktur organisasi } \\
\text { IT }\end{array}$ & $\begin{array}{l}\text { Data Primer: } \\
\text { *Diskripsi pekerjaan } \\
\text { departemen IT sudah } \\
\text { dibakukan. } \\
\text { *Fungsi departemen IT } \\
\text { sudah berjalan sesuai } \\
\text { dengan tugas dan } \\
\text { tanggung jawab yang } \\
\text { telah ditetapka PT. } \\
\text { WMP } \\
\text { *Struktur departemen }\end{array}$ & $\begin{array}{l}\text { *Pengoptimalisasian } \\
\text { struktur organisasi IT } \\
\text { secara tepat lebih } \\
\text { merefleksikan pada } \\
\text { kebutuhan usaha } \\
\text { dengan memberikan } \\
\text { pelayanan yang sejalan } \\
\text { dengan proses strategi } \\
\text { usaha dari pada dengan } \\
\text { teknologi yang } \\
\text { terisolasi. } \\
\text { *Struktur organisasi } \\
\text { lebih fleksibel dan }\end{array}$ & $\begin{array}{l}\text { *PT. WMP } \\
\text { melaksanakan } \\
\text { kesesuaian dan } \\
\text { pengevaluasian } \\
\text { pelaksanaan } \\
\text { organisasi dan } \\
\text { tanggung jawab. } \\
\text { *Sesuai dengan } \\
\text { pembahasan point } \\
\text { 1, PT. WMP } \\
\text { menetapkan } \\
\text { prosedur baku. }\end{array}$ \\
\hline
\end{tabular}




\begin{tabular}{|c|c|c|c|c|}
\hline No & $\begin{array}{l}\text { Perencanaan \& } \\
\text { Pengorganisasian }\end{array}$ & Saat ini & $\begin{array}{c}\text { Target-Rekomendasi } \\
\text { Cobit }\end{array}$ & Strategi \\
\hline & & $\begin{array}{l}\text { IT bersifat fleksible } \\
\text { dan mudah beradaptasi } \\
\text { sesuai dengan } \\
\text { kebutuhan PT. WMP. } \\
\text { Data sekunder } \\
\text { : } \\
\text { *Manajemen IT } \\
\text { bertanggung jawab } \\
\text { pada hubungan dan } \\
\text { struktur organisasi IT. } \\
\text { *Hubungan dan } \\
\text { struktur organisasi IT } \\
\text { dinyatakan beresiko } \\
\text { tinggi dan penting. } \\
\text { *Kemampuan dari } \\
\text { manajemen IT dalam } \\
\text { hubungan dan struktur } \\
\text { organisasi IT dianggap } \\
\text { sedang mendekati baik. } \\
\text { *Evaluasi dari } \\
\text { hubungan dan struktur } \\
\text { organisasi sedang dan } \\
\text { dokumentasi sudah } \\
\text { dilaksanakan. }\end{array}$ & $\begin{array}{l}\text { mudah beradaptasi. } \\
\text { Terdapat pengertian } \\
\text { formal atas hubungan } \\
\text { antara penggunaan dan } \\
\text { pihak ke tiga. } \\
\text { *Pengalaman PT } \\
\text { WMP telah dilakukan. } \\
\text { Proses pengembangan } \\
\text { dan manajemen } \\
\text { struktur organisasi } \\
\text { adalah sulit diikuti dan } \\
\text { terencana dengan baik. } \\
\text { Pengetahuan teknis } \\
\text { secara umum baik } \\
\text { internal dan eksternal } \\
\text { telah dilaksanakan. } \\
\text { *Terdapat penggunaan } \\
\text { teknologi yang luas } \\
\text { untuk membantu } \\
\text { kesesuaian } \\
\text { pelaksanaan organisasi } \\
\text { dan tanggung jawab. } \\
\text { *Pengaruh teknologi } \\
\text { IT untuk membantu } \\
\text { organisasi yang } \\
\text { kompleks, terdistribusi } \\
\text { secara geografi dan } \\
\text { organisasi } \\
\text { virtual.Proses } \\
\text { kemajuan berkala telah } \\
\text { diterapkan. }\end{array}$ & \\
\hline 5 & $\begin{array}{l}\text { Pengelolaan } \\
\text { Investasi IT }\end{array}$ & $\begin{array}{l}\text { Data primer: } \\
\text { *Manajemen investasi } \\
\text { IT sangat penting bagi } \\
\text { PT. WMP } \\
\text { *PT. WMP belum } \\
\text { memeliki prosedur } \\
\text { pembuatan anggaran. }\end{array}$ & $\begin{array}{l}\text { * Manajemen } \\
\text { pemengang tanggung } \\
\text { jawab dan perhitungan } \\
\text { untuk pemilihan } \\
\text { investasi dan } \\
\text { pendanaan ditugaskan } \\
\text { pada orang tertentu. } \\
\text { *Jenis pendanaan telah } \\
\text { diidentifikasikan dan }\end{array}$ & $\begin{array}{l}\text { *Sesuai dengan } \\
\text { pembahasan point } \\
1 \text { PT. WMP } \\
\text { menetapkan } \\
\text { prosedur baku. } \\
\text { *Prosedur baku } \\
\text { pembuatan; } \\
\text { pengelolaan dan } \\
\text { pendanaan }\end{array}$ \\
\hline
\end{tabular}




\begin{tabular}{|c|c|c|c|c|}
\hline No & $\begin{array}{c}\text { Perencanaan \& } \\
\text { Pengorganisasian }\end{array}$ & Saat ini & $\begin{array}{c}\text { Target-Rekomendasi } \\
\text { Cobit }\end{array}$ & Strategi \\
\hline & & $\begin{array}{l}\text { *Penyusunan anggaran } \\
\text { berada pada wewenang } \\
\text { manajer IT } \\
\text { * Dalam penentuan } \\
\text { investasi IT sudah } \\
\text { mempertimbangkan } \\
\text { tren teknologi ke depan } \\
\text { dan menganalisa } \\
\text { alternative } \\
\text { pembiayaan. } \\
\text { Data sekunder : } \\
\text { *Manajemen IT } \\
\text { bertanggung jawab } \\
\text { pada pengelolaan } \\
\text { investasi IT. } \\
\text { *Pengelolaaan } \\
\text { investasi IT dinyatakan } \\
\text { beresiko tinggi dan } \\
\text { penting. } \\
\text { *Kemampuan dari } \\
\text { manajemen IT dalam } \\
\text { mengelola investasi IT } \\
\text { dianggap sedang. } \\
\text { *Evaluasi dari } \\
\text { pengelolaan investasi } \\
\text { IT sedang dan } \\
\text { dokumentasi masih } \\
\text { kurang. }\end{array}$ & $\begin{array}{l}\text { dipecahkan. Tenaga IT } \\
\text { memiliki pengalaman } \\
\text { dan pengetahuan yang } \\
\text { cukup untuk } \\
\text { membangun } \\
\text { perencanaan } \\
\text { pendanaan IT dan } \\
\text { merekomendasikan } \\
\text { investasi IT yang } \\
\text { sesuai. } \\
\text { *Analisa biaya secara } \\
\text { formal disajikan } \\
\text { mencakup biaya secara } \\
\text { langsung maupun tidak } \\
\text { langsung atas operasi } \\
\text { yang ada demikian } \\
\text { pula dengan investasi } \\
\text { yang direncanakan } \\
\text { dengan menggunakan } \\
\text { konsep kepemilikan } \\
\text { dari total pembiayaan } \\
\text { *Suatu proses } \\
\text { standardisasi dan } \\
\text { proaktif untuk } \\
\text { pendanaan telah } \\
\text { dilaksanakan. } \\
\text { *Perubahan } \\
\text { pengembangan dan } \\
\text { biaya operasi dari } \\
\text { perangkat keras dan } \\
\text { perangkat lunak ke } \\
\text { system integrasi dan } \\
\text { sumber daya IT } \\
\text { dikenal dalam } \\
\text { perencanaan investasi. }\end{array}$ & $\begin{array}{l}\text { perencanaan } \\
\text { investasi }\end{array}$ \\
\hline 6 & $\begin{array}{l}\text { Pengkomunikasian } \\
\text { Tujuaan dan } \\
\text { sasaran } \\
\text { Manajemen }\end{array}$ & $\begin{array}{l}\text { Data primer: } \\
\text { *Pengembangan } \\
\text { komunikasi dan proses } \\
\text { yang terkait } \\
\text { dilaksanakan secara }\end{array}$ & $\begin{array}{l}\text { *Pimpinan menerima } \\
\text { tanggung jawab untuk } \\
\text { kebijaksanaan } \\
\text { kesesuaian komunikasi } \\
\text { internal dan telah } \\
\text { mendelegasikan }\end{array}$ & $\begin{array}{l}\text { *Pimpinsn } \\
\text { bertanggung } \\
\text { jawab atas } \\
\text { kebijaksanaan } \\
\text { kesesuaian } \\
\text { komunikasi }\end{array}$ \\
\hline
\end{tabular}




\begin{tabular}{|c|c|c|c|c|}
\hline No & $\begin{array}{c}\text { Perencanaan \& } \\
\text { Pengorganisasian }\end{array}$ & Saat ini & $\begin{array}{c}\text { Target-Rekomendasi } \\
\text { Cobit }\end{array}$ & Strategi \\
\hline & & $\begin{array}{l}\text { informal dan in } \\
\text { konsisten. } \\
\text { *Pengertian tentang } \\
\text { kebutuhan keefektifan } \\
\text { pengendalian informasi } \\
\text { dimengerti secara } \\
\text { implicit oleh } \\
\text { manajemen dengan } \\
\text { dokumentasi } \\
\text { inkonsistensi dan } \\
\text { dilakukan secara } \\
\text { informa } \\
\text { l } \\
\text { *PT. WMP memiliki } \\
\text { arah dan tujuan yang } \\
\text { menjadi standar } \\
\text { *PT. WMP memiliki } \\
\text { prosedur untuk } \\
\text { memastikan keamanan } \\
\text { IT dan memiliki } \\
\text { program untuk } \\
\text { meningkatkan } \\
\text { kesadaran karyawan } \\
\text { akan pentingnya } \\
\text { keamanan IT. } \\
\text { *PT. WMP melakukan } \\
\text { pengecekan ulang dan } \\
\text { pembaharuan arah dan } \\
\text { tujuan PT. WMP. } \\
\text { *Sosialisasi arah dan } \\
\text { tujuan PT. WMP } \\
\text { belum seluruhnya } \\
\text { disosialisasikan } \\
\text { keseluruh karyawan. } \\
\text { Data sekunder : } \\
\text { bertanggung jawab } \\
\text { pada pengkomunikasi }\end{array}$ & $\begin{array}{l}\text { tanggug jawab dan } \\
\text { mengalokasikan tenaga } \\
\text { secukupnya guna } \\
\text { menjaga suasana yang } \\
\text { sejalan dengan } \\
\text { perubahan-perubahan } \\
\text { signifikan. } \\
\text { *Suasana kesesuaian } \\
\text { informasi yang positif } \\
\text { dan proaktif termasuk } \\
\text { kualitas komitmen dan } \\
\text { perhatian atas } \\
\text { keamanan IT, telah } \\
\text { dilaksanakan. } \\
\text { *Suatu kebijaksanaan } \\
\text { prosedur dan standar } \\
\text { yang lengkap telah } \\
\text { dibuat, dipelihara dan } \\
\text { dikomunikasikan dan } \\
\text { merupakan } \\
\text { pengalaman internal } \\
\text { yang terbaik. Suatu } \\
\text { panduan untuk tingkat } \\
\text { tertentu dan diikuti } \\
\text { daftar kebutuhan telah } \\
\text { dibuat. }\end{array}$ & $\begin{array}{l}\text { internal } \\
\text { *PT.WMP } \\
\text { melaksanakan } \\
\text { kebijaksanaan, } \\
\text { prosedur dan } \\
\text { standar baku } \\
\text { dibuat dikelola, } \\
\text { dikomunikasikan } \\
\text { dan } \\
\text { didokumentasikan } \\
\text { berikut panduan } \\
\text { untuk tingkat } \\
\text { tertentu dan } \\
\text { diikuti daftar } \\
\text { kebutuhan. }\end{array}$ \\
\hline
\end{tabular}




\begin{tabular}{|c|c|c|c|c|}
\hline No & $\begin{array}{c}\text { Perencanaan \& } \\
\text { Pengorganisasian }\end{array}$ & Saat ini & $\begin{array}{c}\text { Target-Rekomendasi } \\
\text { Cobit }\end{array}$ & Strategi \\
\hline & & $\begin{array}{l}\text { an tujuan dan sasaran } \\
\text { manajemen. } \\
\text { * Pengelolaan } \\
\text { pengkomunikasian } \\
\text { tujuan dan sasaran } \\
\text { manajemen di } \\
\text { nyatakan beresiko } \\
\text { tinggi dan penting. } \\
\text { *Kemampuan dari } \\
\text { manajemen IT dalam } \\
\text { mensosialisasikan } \\
\text { tujuan dan sasaran } \\
\text { manajemen dianggap } \\
\text { sedang. } \\
\text { *Evaluasi kurang dan } \\
\text { dokumentasi sedang. }\end{array}$ & & \\
\hline 7 & $\begin{array}{l}\text { Pengelolaan } \\
\text { sumber daya } \\
\text { manusia }\end{array}$ & $\begin{array}{l}\text { Data primer : } \\
\text { *Manajemen SDM } \\
\text { merupakan sesuatu } \\
\text { yang penting bagi PT } \\
\text { WMP walaupun } \\
\text { pengertian tentang } \\
\text { kualifikasi sumber } \\
\text { daya manusia untuk IT } \\
\text { departemen terkadang } \\
\text { masih kabur. } \\
\text { *PT WMP memiliki } \\
\text { rencana SDM. } \\
\text { *Ada petugas yang } \\
\text { bertanggung jawab } \\
\text { dalam menyusun } \\
\text { rencana SDM tersebut. } \\
\text { Rencana SDM sejalan } \\
\text { dengan strategi PT. } \\
\text { WMP }\end{array}$ & $\begin{array}{l}\text { *Tanggung jawab } \\
\text { untuk membangun dan } \\
\text { memelihara rencana } \\
\text { sumber daya IT telah } \\
\text { dibuat ditugaskan } \\
\text { kepada orang tertentu } \\
\text { dengan pengalaman } \\
\text { dan kemampuan yang } \\
\text { cukup untuk membuat } \\
\text { dan memelihara } \\
\text { rencana tersebut. } \\
\text { *Proses telah resposif } \\
\text { terhadap perubahan. } \\
\text { *Organisasi memiliki } \\
\text { pengukuran standar } \\
\text { yang memungkinkan } \\
\text { menentukan deviasi } \\
\text { rencana dengan } \\
\text { penekanan pada } \\
\text { pertumbuhan dan } \\
\text { perputaran tenaga IT. }\end{array}$ & $\begin{array}{l}\text { *Adanya } \\
\text { tanggung jawab } \\
\text { untuk memilih, } \\
\text { membangun dan } \\
\text { memelihara } \\
\text { rencana sumber } \\
\text { daya IT dengan } \\
\text { standard dan } \\
\text { prosedur tertentu. } \\
\text { *PT. WMP } \\
\text { mempunyai } \\
\text { standar } \\
\text { kualifikasi dan } \\
\text { kinerja sumber } \\
\text { daya manusia. } \\
\text { *PT. WMP } \\
\text { melaksanakan } \\
\text { skala kompensasi } \\
\text { secara periodic. }\end{array}$ \\
\hline
\end{tabular}




\begin{tabular}{|c|c|c|c|c|}
\hline No & $\begin{array}{c}\text { Perencanaan \& } \\
\text { Pengorganisasian }\end{array}$ & Saat ini & $\begin{array}{c}\text { Target-Rekomendasi } \\
\text { Cobit }\end{array}$ & Strategi \\
\hline & & $\begin{array}{l}\text { analisa system } \\
\text { kompensasi pada } \\
\text { karyawan departemen } \\
\text { IT. } \\
\text { *PT WMP melakukan } \\
\text { program rotasi bagi } \\
\text { sebagian karyawan IT. } \\
\text { *PT WMP } \\
\text { memberikan insentif } \\
\text { bagi karyawan IT yang } \\
\text { berprestasi. } \\
\text { Data sekunder : } \\
\text { *Manajemen IT pada } \\
\text { pengelolaan sumber } \\
\text { daya manusia dianggap } \\
\text { sedang. } \\
\text { *Pengelolaan SDM } \\
\text { dinyatakan beresiko } \\
\text { tinggi dan penting. } \\
\text { *Kemampuan dari } \\
\text { manajemen IT dalam } \\
\text { mengelola SDM } \\
\text { dianggap sedang. } \\
\text { *Evaluasi dari } \\
\text { pengelolaan SDM baik } \\
\text { dan dokumentasi } \\
\text { masih kurang. }\end{array}$ & $\begin{array}{l}\text { *Analisa skala } \\
\text { kompensasi dilakukan } \\
\text { secara periodic guna } \\
\text { menyakinkan bahwa } \\
\text { gaji yang diberikan } \\
\text { kompetitif dengan } \\
\text { organisasi IT yang } \\
\text { lain. } \\
\text { *Sumber daya IT } \\
\text { proaktif dalam } \\
\text { menentukan kemajuan } \\
\text { karir. }\end{array}$ & \\
\hline 8 & $\begin{array}{l}\text { Kepastian } \\
\text { kebutuhan sesuai } \\
\text { dengan } \\
\text { permintaan } \\
\text { eksternal }\end{array}$ & $\begin{array}{l}\text { Data primer: } \\
\text { *Bagi PT. WMP } \\
\text { pemenuhan } \\
\text { persyaratan eksternal } \\
\text { adalah penting. } \\
\text { *Ada fungsi sentral } \\
\text { yang } \\
\text { mengkoordinasikan }\end{array}$ & $\begin{array}{l}\text { *Terdapat pengertian } \\
\text { atas masalah dan } \\
\text { pengalaman dari } \\
\text { permintaan eksternal } \\
\text { dan kebutuhan untuk } \\
\text { menyakinkan hal-hal } \\
\text { pada setiap tingkat. } \\
\text { *Terdapat rencana } \\
\text { pelatihan formal yang }\end{array}$ & $\begin{array}{l}\text { *PT. WMP } \\
\text { melakukan } \\
\text { pelatihan formal } \\
\text { dan } \\
\text { pengevaluasian } \\
\text { permintaan } \\
\text { eksternal dan } \\
\text { perubahan yang } \\
\text { terjadi. }\end{array}$ \\
\hline
\end{tabular}




\begin{tabular}{|c|c|c|c|c|}
\hline No & $\begin{array}{l}\text { Perencanaan \& } \\
\text { Pengorganisasian }\end{array}$ & Saat ini & $\begin{array}{c}\text { Target-Rekomendasi } \\
\text { Cobit }\end{array}$ & Strategi \\
\hline & & $\begin{array}{l}\text { keseluruh an PT. WMP } \\
\text { jika terdapat perubahan } \\
\text { peraturan. } \\
\text { *Seluruh karyawan } \\
\text { akan sadar / tahu, jika } \\
\text { ada perubahan } \\
\text { peraturan dari luar } \\
\text { yang meliputi PT. } \\
\text { WMP } \\
\text { *Aada prosedur untuk } \\
\text { merespon perubahan } \\
\text { peraturan dari luar, dan } \\
\text { melakukan evaluasi } \\
\text { dan monitoring } \\
\text { terhadap prosedur } \\
\text { tersebut. } \\
\text { *Jika ada perubahan } \\
\text { peraturan, PT. WMP } \\
\text { melaksanakan } \\
\text { pelatihan tetapi tidak } \\
\text { untuk semua } \\
\text { karyawan. } \\
\text { *Kemampuan dari } \\
\text { manajemen IT dalam } \\
\text { kebutuhan sesuai } \\
\text { dengan permintaan } \\
\text { * Manajemen IT pada } \\
\text { kepastian kebutuhan } \\
\text { sesuai dengan } \\
\text { permintaan eksternal } \\
\text { dianggap sedang. } \\
\text { *Kebutuhan sesuai } \\
\text { dengan permintaan } \\
\text { eksternal dinyatakan } \\
\text { beresiko tinggi dan } \\
\text { tidak begitu penting. } \\
\end{array}$ & $\begin{array}{l}\text { pasti bahwa semua } \\
\text { karyawan memberikan } \\
\text { perhatian sesuai } \\
\text { kewajiban-kewajiban } \\
\text { mereka. } \\
\text { *Tanggung jawab yang } \\
\text { jelas dan proses } \\
\text { kepemilikan dapat } \\
\text { dimengerti. Proses } \\
\text { tersebut meliputi } \\
\text { pengevaluasian } \\
\text { suasana guna } \\
\text { mengidentifikasikan } \\
\text { eksternal dan } \\
\text { perubahan yang terjadi } \\
\text { *Terdapat mekanisasi } \\
\text { untuk menempatkan } \\
\text { kesesuaian non } \\
\text { compliance dengan } \\
\text { permintaan eksternal, } \\
\text { kekuatan pengalaman } \\
\text { internal dan } \\
\text { implementasi } \\
\text { pelaksanaan yang } \\
\text { benar. } \\
\text { *Masalah non } \\
\text { compliance dianalisis } \\
\text { guna mengetahui akar } \\
\text { pengalaman internal } \\
\text { perbaik adalah } \\
\text { dilakukan untuk } \\
\text { kebutuhan yang } \\
\text { yang watifik seperti } \\
\text { tujuan untuk dengan cara } \\
\text { mengidentifikasian } \\
\text { solusi yang tepat. } \\
\text { pang berlaku }\end{array}$ & $\begin{array}{l}\text { *Standardisasi } \\
\text { pelatihan dan } \\
\text { evaluasi. }\end{array}$ \\
\hline
\end{tabular}




\begin{tabular}{|c|c|c|c|c|}
\hline No & $\begin{array}{c}\text { Perencanaan \& } \\
\text { Pengorganisasian }\end{array}$ & Saat ini & $\begin{array}{c}\text { Target-Rekomendasi } \\
\text { Cobit }\end{array}$ & Strategi \\
\hline & & $\begin{array}{l}\text { eksternal dianggap } \\
\text { sedang. } \\
\text { *Evaluasi dan } \\
\text { dokumentasi masih } \\
\text { kurang. }\end{array}$ & $\begin{array}{l}\text { dan recurring service } \\
\text { contracts. }\end{array}$ & \\
\hline 9 & Perkiraan resiko & $\begin{array}{l}\text { Data primer : } \\
\text { *Perkiraan resiko } \\
\text { pentig bagi PT. WMP. } \\
\text { *Perkiraan resiko } \\
\text { dilakukan disemua } \\
\text { proses bisniks PT. } \\
\text { WMP walaupun } \\
\text { perkiraan resiko } \\
\text { tersebut terkadang } \\
\text { dilakukan hanya pada } \\
\text { proyek-proyek penting } \\
\text { saja. } \\
\text { *PT. WMP memiliki } \\
\text { prosedur perkiraan } \\
\text { resiko yang } \\
\text { distandardisasi dan } \\
\text { didokumentasikan. } \\
\text { *Pelaksana perkiraan } \\
\text { resiko ada ditingkat top } \\
\text { manajemen } \\
\text { *Memiliki database } \\
\text { manajemen resiko. } \\
\text { Data sekunder : } \\
\text { *Manajemen IT } \\
\text { bertanggung jawab } \\
\text { pada perkiraan resiko } \\
\text { sangat tinggi. } \\
\text { *Perkiraan resiko } \\
\text { dinyatakan sangat } \\
\text { tinggi dan tidak begitu }\end{array}$ & $\begin{array}{l}\text { *Pengujian resiko telah } \\
\text { dibuat guna } \\
\text { menentukan dimana } \\
\text { struktur dan proses } \\
\text { organisasi yang luas } \\
\text { dibangun, diikuti } \\
\text { secara berkala dan } \\
\text { terencana dengan baik. } \\
\text { *Rersiko } \\
\text { brainstorming dan } \\
\text { analisa akar penyebab } \\
\text { menyertakan orang- } \\
\text { orang berpengalaman } \\
\text { telah dilaksanakan } \\
\text { melalui seluruh } \\
\text { organisasi, } \\
\text { Menangkap, } \\
\text { menganalisa dan } \\
\text { melaporkan data resiko } \\
\text { manajemen dilakukan } \\
\text { secara otomatis. } \\
\text { *Panduan dibuat dari } \\
\text { pimpinan pada daerah } \\
\text { dan organisasi ikut } \\
\text { serta dalam group guna } \\
\text { pertukaran } \\
\text { pengalaman. } \\
\text { *Resiko manajemen } \\
\text { terintegrasi dengan } \\
\text { baik dalam semua } \\
\text { bisnis dan operasi IT, } \\
\text { diterima dan tergabung } \\
\text { dalam pengguna jasa } \\
\text { IT. }\end{array}$ & $\begin{array}{l}\text { *Perkiraan dan } \\
\text { pengujian resiko } \\
\text { dilakukan pada } \\
\text { setiap proses } \\
\text { bisnis PT. WMP } \\
\text { secara berkala } \\
\text { dan terencana } \\
\text { dengan baik. } \\
\text { *PT. WMP } \\
\text { melaksanakan } \\
\text { prosedur baku } \\
\text { perkiraan resiko } \\
\text { dan } \\
\text { terdokumentasi } \\
\text { dimana panduan } \\
\text { prosedur tersebut } \\
\text { dibuat pimpinan } \\
\text { PT. WMP. } \\
\text { *Resiko } \\
\text { disosialisasi kan } \\
\text { kepada seluruh } \\
\text { manajemen. }\end{array}$ \\
\hline
\end{tabular}




\begin{tabular}{|c|c|c|c|c|}
\hline No & $\begin{array}{l}\text { Perencanaan \& } \\
\text { Pengorganisasian }\end{array}$ & Saat ini & $\begin{array}{c}\text { Target-Rekomendasi } \\
\text { Cobit }\end{array}$ & Strategi \\
\hline & & $\begin{array}{l}\text { penting. } \\
\text { *Kemampuan dari } \\
\text { manajemen IT dalam } \\
\text { mengelola sumber } \\
\text { daya manusia dianggap } \\
\text { sedang. } \\
\text { *Evaluasi dan } \\
\text { dokumentasi baik. }\end{array}$ & & \\
\hline 10 & $\begin{array}{l}\text { Pengelolaan } \\
\text { proyek-proyek }\end{array}$ & $\begin{array}{l}\text { Data primer: } \\
\text { *PT WMP menyadari } \\
\text { pentingngnya } \\
\text { manajemen proyek IT } \\
\text { *PT WMP sudah } \\
\text { memiliki prosedur } \\
\text { manajemen proyek IT } \\
\text { yang standar. } \\
\text { *Top manajemen dan } \\
\text { seluruh karyawan tidak } \\
\text { selalu mendukung dan } \\
\text { memback up setiap } \\
\text { proyek IT. } \\
\text { *Setiap proyek IT } \\
\text { memiliki jadwal } \\
\text { anggaran dan alat } \\
\text { penilaian kinerja. } \\
\text { *Struktur organisasi } \\
\text { proyek sudah tetap. } \\
\text { *Tujuan proyek IT } \\
\text { sudah sejalan dengan } \\
\text { tujuan PT. WMP } \\
\text { *Tidak semua anggota } \\
\text { tim proyek sudah } \\
\text { mengikuti pelatihan } \\
\text { yang berkaitan dengan } \\
\text { proyek IT. }\end{array}$ & $\begin{array}{l}\text { *Pimpinan } \\
\text { membutuhkan } \\
\text { pengukuran formal dan } \\
\text { standard an pelatihan } \\
\text { pembelajara untuk } \\
\text { mengevaluasi } \\
\text { pelaksanaan } \\
\text { penyelesaian proyek. } \\
\text { *Manajemen proyek } \\
\text { mengukur dan } \\
\text { mengevaluasi } \\
\text { organisasi dan tidak } \\
\text { hanya dalam IT. } \\
\text { Kemajuan proses } \\
\text { manajemen proyek } \\
\text { terformulasikan dan } \\
\text { dikomunikasikan } \\
\text { *Pelatihan anggota } \\
\text { proyek di segala aspek. } \\
\text { *Resiko manajemen } \\
\text { dilakukan sebagai } \\
\text { bagian dari proses } \\
\text { manajemen proyek. } \\
\text { Stakeholder secara } \\
\text { aktif berpartisipasi } \\
\text { dalam proyek atau } \\
\text { memimpin mereka. } \\
\text { *Jangka waktu proyek } \\
\text { dan criteria untuk } \\
\text { mengevaluasi }\end{array}$ & $\begin{array}{l}\text { *PT WMP } \\
\text { memiliki } \\
\text { pengukuran } \\
\text { standar untuk } \\
\text { manajemen } \\
\text { (termasuk } \\
\text { keuntungan dan } \\
\text { kerugian proyek) } \\
\text { beserta standar } \\
\text { evaluasi atas } \\
\text { pelaksanaan } \\
\text { proyek, sebagai } \\
\text { contoh jangka } \\
\text { waktu proyek dan } \\
\text { criteria untuk } \\
\text { mengevaluasi } \\
\text { kesuksesan } \\
\text { proyek } \\
\text { * } \\
\text { Proyek } \\
\text { dikomunikasikan } \\
\text { pada tingkat } \\
\text { manajemen guna } \\
\text { menyamakan } \\
\text { persepsi dan } \\
\text { dukungan atas } \\
\text { proyek tersebut. } \\
\text { *PT WMP } \\
\text { memberikan } \\
\text { pelatihan formal } \\
\text { bagi anggota tim } \\
\text { proyek. }\end{array}$ \\
\hline
\end{tabular}




\begin{tabular}{|c|c|c|c|c|}
\hline No & $\begin{array}{c}\text { Perencanaan \& } \\
\text { Pengorganisasian }\end{array}$ & Saat ini & $\begin{array}{c}\text { Target-Rekomendasi } \\
\text { Cobit }\end{array}$ & Strategi \\
\hline & & $\begin{array}{l}\text { Data sekunder : } \\
\text { *Manajemen IT } \\
\text { bertanggung jawab } \\
\text { pada pengelolaan } \\
\text { proyek } \\
\text { * Pengelolaan proyek } \\
\text { dinyatakan beresiko } \\
\text { sangat tinggi dan } \\
\text { penting. } \\
\text { *Kemampuan dari } \\
\text { manajemen IT dalam } \\
\text { mengelola proyek di } \\
\text { anggap sedang. } \\
\text { *Evaluasi kurang dan } \\
\text { dokumentasi sedang. }\end{array}$ & $\begin{array}{l}\text { kesuksesan setiap } \\
\text { jangka waktu telah } \\
\text { dilakukan. } \\
\text { * Keuntungan dan } \\
\text { resiko di ukur dan } \\
\text { dikelola terlebih } \\
\text { dahulu, selama dan } \\
\text { setelah penyelesaian } \\
\text { proyek, pimpinan telah } \\
\text { membuat program } \\
\text { fungsi manajemen } \\
\text { dalam IT } \\
\text { * Proyek ditentukan, } \\
\text { staff dan dikelola lebih } \\
\text { ditunjukan kemajuan } \\
\text { cita-cita PT WMP dari } \\
\text { pada hal-hal spesifik } \\
\text { mengenai IT. }\end{array}$ & \\
\hline 11 & $\begin{array}{l}\text { Pengelolaan } \\
\text { kualitas }\end{array}$ & $\begin{array}{l}\text { Data primer : } \\
\text { *PT WMP melakukan } \\
\text { perencanaan dan } \\
\text { monitoring terhadap } \\
\text { pelaksanaan } \\
\text { manajemen kualitas. } \\
\text { *PT WMP melakukan } \\
\text { survey untuk } \\
\text { mengukur tingkat } \\
\text { kepuasan pengguna } \\
\text { terhadap kualitas IT. } \\
\text { *Pelatihan kualitas } \\
\text { dilakukan keseluruh } \\
\text { karyawan. } \\
\text { *Perusahaan belum } \\
\text { sepenuhnya memiliki } \\
\text { standar kualitas. } \\
\text { *PT WMP melakukan } \\
\text { review / evaluasi }\end{array}$ & $\begin{array}{l}\text { *Organisasi secara } \\
\text { berkala dan konsisten } \\
\text { mengukur kualitas, } \\
\text { jasa produk dan } \\
\text { proyek;. Kualitas } \\
\text { tersebut ditunjukan } \\
\text { dalam segala proses, } \\
\text { termasuk proses } \\
\text { sehubungan dengan } \\
\text { pihak ketiga. } \\
\text { *Dasar standarnisasi } \\
\text { pengetahuan dibuat } \\
\text { untuk metric kualitas. } \\
\text { Survey atas kualitas } \\
\text { kepuasan merupakan } \\
\text { proses yang berjalan } \\
\text { dan menuntun kepada } \\
\text { analisa akar } \\
\text { permasalahan. } \\
\text { *Metoda analisa biaya } \\
\text { dan keuntungan } \\
\text { digunakan untuk }\end{array}$ & $\begin{array}{l}\text { *PT WMP } \\
\text { memiliki standar } \\
\text { perencanaan, } \\
\text { monitoring dan } \\
\text { mengevaluasi } \\
\text { manajemen } \\
\text { kualitas secara } \\
\text { berkala. } \\
\text { *PT WMP } \\
\text { memerlukan studi } \\
\text { banding dengan } \\
\text { perusahaan } \\
\text { sejenis. }\end{array}$ \\
\hline
\end{tabular}




\begin{tabular}{|c|c|c|c|c|}
\hline No & $\begin{array}{c}\text { Perencanaan \& } \\
\text { Pengorganisasian }\end{array}$ & Saat ini & $\begin{array}{c}\text { Target-Rekomendasi } \\
\text { Cobit }\end{array}$ & Strategi \\
\hline & & $\begin{array}{l}\text { terhadap kualitas. } \\
\text { *PT WMP tidak selalu } \\
\text { melakukan } \\
\text { perbandingan terhadap } \\
\text { industry dan } \\
\text { competitor. } \\
\text { *Kualitas jasa, produk } \\
\text { dan proses penting } \\
\text { bagi perusahaa. } \\
\text { Data sekunder } \\
\text { : } \\
\text { *Manajemen IT } \\
\text { bertanggung jawab } \\
\text { pada pengelolaan } \\
\text { kualitas. } \\
\text { *Pengelolaan kualitas } \\
\text { dinyatakan beresiko } \\
\text { tinggi dan penting. } \\
\text { *Kemampuan dari } \\
\text { manajemen IT dalam } \\
\text { mengelola investasi IT } \\
\text { dianggap sedang. } \\
\text { *Evaluasi dan } \\
\text { dokumentasi sedang. }\end{array}$ & $\begin{array}{l}\text { mengukur kualitas } \\
\text { inisiatif. Terdapat } \\
\text { kemajuan pada } \\
\text { tanggung jawab dan } \\
\text { perhitungan proses } \\
\text { bisnis organisasi dan } \\
\text { proses IT. } \\
\text { *Perbandingan antara } \\
\text { norma industry dan } \\
\text { competitor / } \\
\text { persaiangan terjadi } \\
\text { peningkatan. }\end{array}$ & \\
\hline
\end{tabular}

\section{KESIMPULAN DAN SARAN}

\subsection{Kesimpulan}

1. PT. William Makmur Perkasa (PT. WMP) menyadari pentingnya kesesuaian perencanaan strategis IT, baik jangka pendek dan jangka panjang dengan tujuan PT. WMP.

2. Kesesuaian misi dan tujuan PT. WMP telah dilaksanakan biarpun perlu adanya beberapa koreksi, seperti cara pandang para perencanaan strategis it, penggunaan prosedur standar sesuai dengan standar internasional, pendokumentasian, prosedur pelaksanaan, pelaksanaan operasional prosedur pembuatan arsitektur sistem, prosedur pengembangan software, prosedur sumber daya manusia, diskripsi pekerjaan (job description), prosedur pembuatan anggaran, prosedur resiko manajemen, pelatihan, evaluasi dan prosedur kualitas, sehingga target level maturity yang diharapkan dapat tercapai. 


\subsection{Saran}

Kesesuaian yang telah dilaksanakan tersebut sebaiknya di evaluasi secara berkala melalui pengawasan internal atau pengawasan eksternal (independent audit) untuk mengawasi departemen it secara keseluruhan dan penerapan pengawasan internal ini dapat dilaksanakan dengan menggunakan cobit salah satu metoda kesesuaian it.

\section{DAFTAR PUSTAKA}

Cadbury Report, 2002, Report of the Committee on the Financial Aspects of Corporate Governance.

Cobit Steering Committee and IT Governance Institute, 2000, Control Objectives, Informaton System Audit and Control Foundation - IT Governance Institute, United States of America.

Cobit Steering Committee and IT Governance Institute, 2000, Implementation Tools, Informaton System Audit and Control Foundation - IT Governance Institute, United States of America.

Cobit Steering Committee and IT Governance Institute, 2000, Management Guidelines, Informaton System Audit and Control Foundation - IT Governance Institute, United States of America.

Indrajit, Richardus Eko, 2001, Pengantar Konsep Dasar Manajemen Sistem Informasi dan Teknologi Informasi, PT Elex Media Komputindo, Jakarta.

IT Governance Institute, 2001, Board Briefing on IT Governance, Informaton System Audit and Control Foundation - IT Governance Institute, United States of America.

IT Governance Institute, Vol. 3, 2003, The Cobit Maturity Model In A Vendor Evaluation Case, Informaton System Audit and Control Foundation - IT Governance Institute, Available: www.isaca.or.id.

Neuman, W. Lawrence, 2000, Social Research Methods, Allyn and Bacon, United States of America.

Organisation for Economic Co-operation and Development, 1998, Principles of Corporate Governance.

Riduwan, 2002, Skala Pengukuran Variabel-variabel Penelitian, Alfabeta Bandung, Bandung.

Setiawan, Hari Purnomo, Zulkieflimansyah., 1996, Manajemen Strategi: Sebuah Konsep Pengantar, Lembaga Penerbitan Fakultas Universitas Indonesia; Jakarta.

Umar, Husien, 2001, Riset Sumber Daya Manusia Dalam Organisasi, PT Gramedia Pustaka Utama, Jakarta. 